\title{
Complement and Fc Receptors on Cord Blood and Adult Neutrophils
}

\author{
SUSAN H. PROSS $(2+1)$ JAMES A. HALLOCK, RUFUS ARMSTRONG, AND CHARLES W. FISHEL \\ Departments of Medical Microbiology and Pediatrics, University of South Florida College of Medicine, Tampa, \\ Florida, USA
}

\begin{abstract}
Summary
The percentage of neutrophils forming erythrocyte-antibody. complement complex (EAC) and with erythrocyte-antibody complex (EAG) was determined for 30 normal newborns and 10 normal adults. The cord values ranged from 84-100\% EAC binding cells with a mean of $95 \%$. The adult values ranged from $89-100 \%$ EAG binding cells with a mean of $96 \%$ rosetted neutrophils.

The mean percentage of EAG binding cells in the cord samples was $81 \%$, whereas in the seven adult samples the mean was $87 \%$.

\section{Speculation}

Experimental evidence has suggested that the neutrophil of the newborn may be immature compared with that of the adult. In this study we determined that the average percentage of neutrophils possessing complement and Fc receptors in cord blood of normal infants and in adult peripheral blood was identical. Infants suffering from neonatal disorders, including sepsis should be studied for the presence or absence of these receptors.
\end{abstract}

The human neonate has increased susceptibility to infection but the immunologic reasons for this are not well defined $(5$. 12). Immunity involves multiple interrelated specific (humoral and cellular immunity) and nonspecific factors. The function of polymorphonuclear leukocytes is one nonspecific aspect which has been shown (by some investigators) to be decreased in the neonate as compared with the adult with regard to chemotaxis and phagocytosis $(1,2,4,13)$.

Recent reports have identified surface receptors for complement and $\gamma$-globulins $(\mathrm{Fc})$ in adult neutrophils. The complement receptor (assayed by EAC rosettes) is thought to represent the binding ability of the neutrophil, whereas the Fc receptor (assayed by EAG rosettes) is thought to be necessary for ingestion of bound organisms or particles (8).

In view of these reports, and while cognizant of limitations of certain functional assays for determining neutrophil maturity, we developed techniques to analyze cell surface receptors on cord blood neutrophils. Our experiments represent an attempt to further delineate the functional status of neonatal neutrophils. neonatal immunity and, perhaps, the ontogenic development of the immune system.

\section{MATERIALS AND METHODS}

\section{BLOOD SAMPLE COLLECTION}

Thirty cord blood samples from neonates were obtained from random deliveries at Tampa General Hospital. The study includes cord specimens from 11 normal females and 19 normal males of birth weights of $2.1-4.1 \mathrm{~kg}$. None of the infants suffered neonatal difficulties.

The cord was clamped and $10 \mathrm{ml}$ blood collected into a sterile plastic tube containing $0.75 \mathrm{ml}$ heparin $(75 \mathrm{U} / \mathrm{ml})$. The blood was processed within $24 \mathrm{hr}$ of collection. Blood from normal adult volunteers was collected into heparinized syringes $(75 \mathrm{U} /$ $\mathrm{ml}$ ) and analyzed immediately.

\section{ISOLATION OF NEUTROPHILS}

Platelets were removed by centrifuging $10 \mathrm{ml}$ blood at $220 \times g$ for $14 \mathrm{~min}$ at $22^{\circ}$. then centrifuging the plasma at $2.000 \times \mathrm{g}$ for $14 \mathrm{~min}$ at $22^{\circ}$ to recover the platelet-poor plasma. Neutrophils were isolated by differential centrifugation with a method modified from Böyum (3). Ten milliliters of blood were diluted $1: 1$ in saline and $15 \mathrm{ml}$ of Lymphoprep (17) were carefully underlayered. The tubes were centrifuged at $400 \times g$ at the interface for $40 \mathrm{~min}$ at $22^{\circ}$. Three milliliters of the pooled neutrophils and red blood cells plus $3 \mathrm{ml}$ plasma were mixed with $1.2 \mathrm{ml} 4.5 \%$ dextran and incubated at $37^{\circ}$ for $0.5 \mathrm{hr}$. The granulocyte-enriched supernatant was removed and resuspended in incubation media at a concentration of $1.2-1.5 \times 10^{6} \mathrm{cells} / \mathrm{ml}$. This media consisted of Eagle basal medium with Hanks' buffered saline solution (HBSS) plus $5 \%$ heat-inactivated newborn calf serum and streptomycin $(50 \mu \mathrm{g} / \mathrm{ml})$, penicillin $(50 \mathrm{U} / \mathrm{ml})$, neomycin $(50$ $\mu \mathrm{g} / \mathrm{ml}$ ), and $0.03 \%$ sodium bicarbonate.

\section{PREPARATION OF ROSETTES}

Sheep red blood cells (sheep RBC) were combined with immunoglobulin and complement to produce the following suspensions: $E$ which is sheep $R B C$ alone; EAM which is sheep RBC plus hemolysin (rabbit IgM antibody to sheep RBC); EAG which is sheep RBC plus rabbit IgG antibody to sheep RBC; and EAC which is EAM plus complement. The specific procedures for these preparations is as follows. Sheep RBC were obtained each week from Lee Laboratories, Grayson, Georgia. Cells were washed twice in saline and once in HBSS. Heat-inactivated hemolysin, $0.02 \mathrm{ml}(19)$ or heat-inactivated purified $\mathrm{IgG}$ antisheep RBC, $0.02 \mathrm{ml} \mathrm{(19)}$ at one-half the minimum agglutination doses was added to $10 \mathrm{ml}$ of a $2.5 \%$ suspension of sheep RBC. incubated at $37^{\circ}$ for $0.5 \mathrm{hr}$, and washed three times in HBSS to make EAM or EAG, respectively. Mouse complement (whole Dub/ICR mouse serum. $0.2 \mathrm{ml}$ ) was added to $1.8 \mathrm{ml}$ of the EAM suspension, incubated for $0.5 \mathrm{hr}$ at $37^{\circ}$, and washed three times in HBSS to form EAC. The suspensions of EAM. EAG, or EAC were diluted $1: 10$ in incubation medium before use.

\section{ROSETTE PROCEDURE}

Two milliliters of neutrophils in incubation medium were plated onto glass coverslips in petri dishes $(35$ by $10 \mathrm{~mm}(20))$. The cells were incubated at $37^{\circ}$ in a humidified atmosphere, containing 5\% $\mathrm{CO}_{2}$ and $95 \%$ air, for $16-20 \mathrm{hr}$. The cover glasses were washed in HBSS. $2 \mathrm{ml}$ indicator cells were added. and the cells were incubated either at $37^{\circ}$ for $0.5 \mathrm{hr}$ to form EAC rosettes or at room temperature for 1 hr to form EAG rosettes. The cover glasses were washed twice with $2 \mathrm{ml}$ HBSS and the 


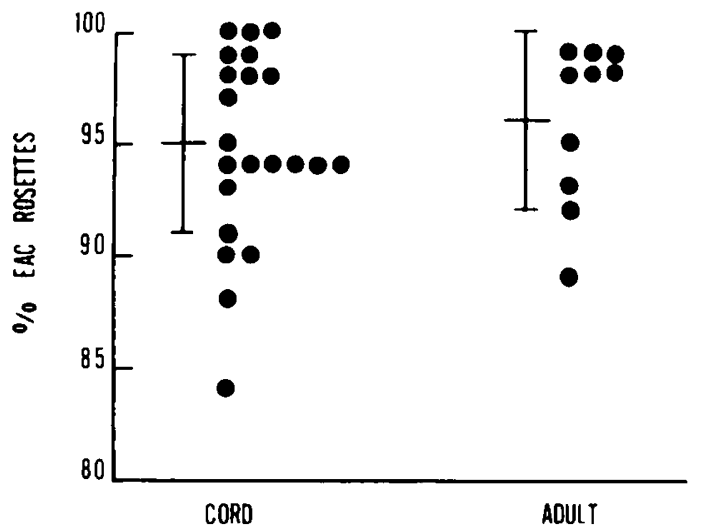

Fig. 1. $E A C$ rosette formation on cord and adult neutrophils. At least 200 cells were counted for each determination. Bars indicate mean and SD.

Table 1. Formation of EAG rosettes as a function of time'

Time of incubation of EAG and neutrophils
Cord samples

1
2
3
4
5
6
7
8
Mean

$\begin{array}{ccc}0.5 \mathrm{hr} & 1 \mathrm{hr} & 2 \mathrm{hr} \\ 24 & 77 & 80 \\ 11 & 70 & 20 \\ 10 & 65 & 31 \\ 47 & 89 & 94 \\ 28 & 91 & 90 \\ 64 & 95 & 91 \\ 38 & 90 & 97 \\ 53 & 90 & 94 \\ 34 & 83 & 74\end{array}$

${ }^{1}$ Results are expressed as the percentage of rosetted versus nonrosetted neutrophils. All incubations were at room temperature. At least 200 cells were counted.

cells were fixed with $2 \mathrm{ml} 3 \%$ gluteraldehyde in phosphate buffer at $\mathrm{pH} 7.4$, washed twice with $2 \mathrm{ml} \mathrm{HBSS}$, air dried, and stained with Wright stain.

\section{RESULTS}

The majority of leukocytes sticking to the coverslips were neutrophils $(>9.5 \%)$. The percentage of EAC forming neutrophils of 22 cord samples and 10 adult samples is compared in Figure 1 . The cord values ranged from $84-100 \%$ EAC binding cells with a mean of $95 \%$. The adults ranged from $89-10(0 \%$ with a mean of $96 \%$ rosetted neutrophils. The Student $t$-test shows that the difference of the cord and adult values are not significant $(P \leq 0.25)$ when the means are compared. Each experiment was controlled by calculating the number of cells binding EAM (erythrocyte hemolysin complex). This nonspecific binding was very low (cord: mean 2.5. SD 2.5; adult mean 2.2, SD 3.1). The average nonspecific binding to unsensitized SRBC was less than $5 \%$ in the cord and in the adult.

In order to investigate the binding to the $\mathrm{Fc}$ receptor of the neutrophils, EAG rosettes were initially formed using the procedure previously described for EAC rosettes, i.e., a $37^{\circ}$ incubation for $0.5 \mathrm{hr}$. The mean percentage of $\mathrm{EAG}$ binding neutrophils in 18 cord samples was $45 \%$ with a SD of 22.4 . In 9 adult samples, the mean was $40 \%$ with a SD of 24 . The slides were difficult to analyze because of the large amount of phagocytosis under these conditions. In order to optimize binding and to minimize phagocytosis, preliminary experiments were performed in which incubation times varied (Table 1). Figure 2 shows the results of analyzing cord and adult samples after a 1-hr, room temperature incubation.
The mean percentage of $\mathrm{EAG}$ in the cord samples was $81 \%$, whereas in the 7 adult samples the mean was $87 \%$. Although the range of values was greater in the cord than the adult, the means were not significantly different as determined by the $t$-test $(P \leq$ $0.25)$. The average nonspecific binding to sheep RBC was determined to be less than $5 \%$ in the cord and the adult samples.

EAC rosettes could also be formed during the 1-hr incubation at room temperature. The mean of 11 cord EAC values was $94 \%$ and the mean of 6 adult samples was $99 \%$ under these conditions. These did not differ significantly from the EAC values determined after an incubation of $0.5 \mathrm{hr}$ at $37 \%$.

\section{DISCUSSION}

Neutrophils have surface receptors for the Fc portion of $\mathrm{IgG}$ and for $\mathrm{C} 3$, the third component of complement. Recent evidence suggests that, as in the macrophage, the complement receptor may be involved in the attachment phase of phagocytosis, whereas binding to the Fc receptor may be necessary for ingestion $(6,14)$.

Adult and neonatal neutrophils bind EAC complexes to the same extent (94-95\% binding cells), Figure 1 . This result is similar to the adult values reported by Wong and Wilson, in 1975 (16). Using different assay conditions, they found that $90 \%$ of the neutrophils formed EAC rosettes.

It is difficult to compare our EAG results with other reports in the literature on a quantitative basis. Although many researchers have reported the existence of $F c$ receptors (as measured by binding to EA complexes) on the neutrophil, in some instances quantitative determinations were not done, in others, no attempt was made to establish optimum conditions, and, often, the antibody used was not the purified IgG fraction (7,11). Our IgG preparation was from a commercial source and not thoroughly analyzed for potential contaminants. Significantly, however, the majority of neutrophils were able to bind and phagocytize EAG preparations but reaction to EAM preparations was minimal.

When binding to EAG was assayed at $37^{\circ}$, the results were low and variable. Similar results were noted by Wong and Wilson (16), who provided evidence suggesting that the Fc receptor may be unstable at $37^{\circ}$. The EAG cells (and to a much lesser extent, the EAM cells) were the only preparations initiating phagocytosis by the neutrophil. Phagocytosis of EAC or unsensitized sheep RBC was never noted.

The variability in numbers of cord and adult neutrophils binding EAG was greater than those binding EAC indicator cells. No

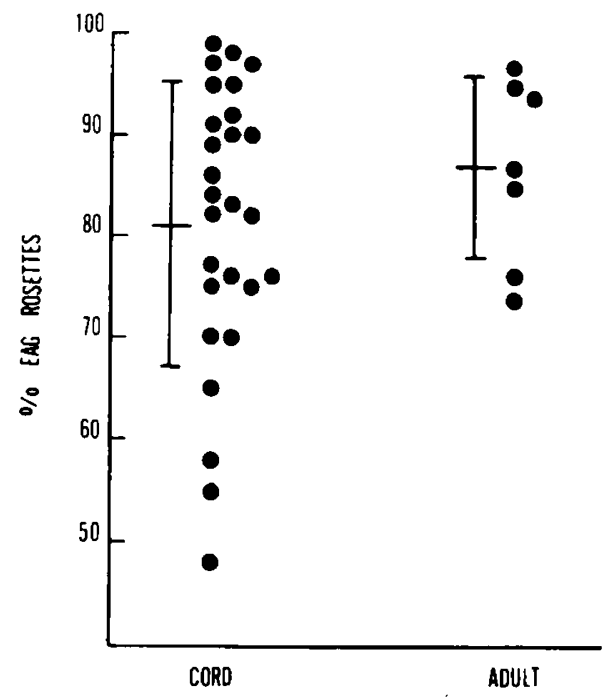

Fig. 2. EAG rosette formation in cord and adult neutrophils. At least 200 cells were counted for each determination. Bars indicate mean and SD. 
correlation was evident between length of time of storage of cord blood or birth weight upon the resultant EAG values. Although three of the cord samples exhibited low EAG values, they were obtained from infants whose medical histories and conditions of delivery appeared to be normal.

Although techniques exist to measure certain functional characteristics of the neutrophil (chemotaxis, ingestion, killing, and metabolism), newborn and adult neutrophils have been compared according to these criteria with varying results $(1,2,4)$. Thus, some investigators report normal phagocvtic activity in neonatal neutrophils, whereas others find diminished activities (9. 10). Similar controversy surrounds the relative maturity of the neonatal bactericidal and metabolic systems (1).

The techniques we have utilized for this study allow for $(l)$ the isolation of a relatively pure population of neutrophils, (2) the selection of relatively healthy cells as measured by their capacity to stick to glass, and (3) the ability to maintain permanent records of the results. However, a possible limitation of the technique should be considered. It is conceivable that the selection for study of a polymorphonuclear (PMN) population by glass adhesiveness may miss a population of PMN's differing between neonates and adults.

As with all studies of surface markers, it is often difficult to strictly relate the existence of the receptors to the ability to perform certain functions. Nevertheless, several studies $(6,14)$ have attempted to correlate the human neutrophil FC and EAC receptors with their ability to phagocytize. It is interesting. therefore. (o) speculate that the lack of these receptors on sufficient numbers of neutrophils may manifest itself in terms of diminished phagocytic ability and susceptibility to infection.

Sepsis remains a significant problem in all neonatal units. A great deal of investigation $(1,2,4,5,9,10,12,15)$ has been performed regarding predisposing immunolegic factors in the newborn. Speculation exists that deficiencies of white cell functions are among these important factors (15). Since we have now demonstrated the presence of receptors in neonatal PMN's. further work is being performed to ascertain whether lack of receptors correlates with development of neonatal sepsis.

\section{CONCLUSION}

Techniques to isolate neutrophils and determine receptor sites for complement and IgG from the peripheral blood of normal adult volunteers and from the cord of healthy neonates are described. The number of neutrophils binding EAC and EAG indicator cells was quantitated. It was found that $95 \%$ of cord and $96 \%$ of adult neutrophils bound EAC, and that $81 \%$ of cord and $87 \%$ of adult neutrophils bound EAG. There were no significant differences in the normal adult and newborn in terms of the mean percentage of neutrophils possessing receptors for these indicator cells. The immunologic significance of these receptors is discussed. It appears that the neutrophil of the normal neonate is as mature as that of the adult in terms of the cell receptors measured.

\section{RIIHERENCI:S AND NOTIS}

1. Bachner. R. L.: Molecular basis for functional disorders of phagocytes. $J$ Pediat., 84: 317 (1974)

2. Bellanti, J. A. Cantz, B. E., Yang, M. C., von Thadden. H., and Schlegel, R. $\mathrm{J}$.: Biochemical changes in human polymorphonuclear leukoytes during maturation. In: J. A. Bellanti and D). H. Davton: The Phagecytic (ell in Host Resistance (Raven Press, New York, 1975).

3. Böyum. A: lsolation of mononuclear cells and granulocytes from human blood. Scand. J. Lab. Clin. Invest. 21 (suppl. 97) (1968).

4. Coen, R.. Grush. O.. and Kauder, E.. Studies of bactericidal activity and metabolism of the leukocyte in full term neonates. J. Pediat., 75: 400 (1964).

5. Davis, R. H. and Galant, S. P.: Nonimmune rosette formation: A measure of the newborn infant's cellular immune response. J. Pediat.. 87: 449 (1975)

6. Griffin, M. Jr.. Bianco, C.. and Silverstein. S. C.: Characterization of the macrophage recepter for complement and demonstration of its functional independence from the receptor for the Fe portion of immunoslobulin $G$. J. Exp. Med. 141: 1267 (1975).

7. Henson. P. M.: The adherence of leukocytes and platelets by fixed $\operatorname{IgG}$ antibody or complement. Immunology, 16: 107 (1969).

8. Mantovani, B.: Different roles of $\mathrm{IgG}$ and complement receptors in phagocytosis by polymorphonuckar leukocytes. J. Immunol.. 115: 15 (1975)

9. Matoth. Y.: Phagocytic and ameboid activities of the leukocytes in the newhorn infant. Pediatrics, 9: 748 (1952).

10. MeCracken. G. H. and Fichenwald, H, F.: Lecukocyte function and the development of opsonic and complement activity in the neonate. Amer. J. Dis. Child. 121: 120 (1971)

11. Messner, R. P.. and Jelinck, J.: Receptors for human and globulins on human neutrophils. J. Clin. Invest . 349: 2165 (1970)

12. Miller M E. The immunodeficiences of immaturity. In: E. R. Stichm and V. A. Fulginiti: Immunologic Disorders of Infants and Children (W. B. Saunders (ompany. Philadelphia, Pa.. 1973)

13. Miller. M. F.: Developmental maturation of human neutrophil motility and its relationship to membrane deformability. In: J. A. Bellanti and D. H. Dayton: The Phagocytic Cell in Host Resistance (Raven Press. New York. $1975)$

14. Scribner, D. J., and Fahrney, D.: Neutrophil receptors for IgG and complement: Their roles in the attachment and ingestion phases of phagocytosis. J. Immunol. 1/6: 892 (1976).

15. Wilson. D, H., and Eichenwald, H. F.: Sepsis neonatorum. Pediat. (lin. N Amer., 2l: 571 (1974).

16. Wong. L... and Wilsen, J. D.: The identification of Fe and ( 3 receptors on human neutrophils. J. Immunol Methods, 7: 69 (1975)

17. Gallard-Schlesinger Corp.. Carle Place, New York, N.Y.

18. International Science Industries. Gary. III.

19. Difco. Detroit, Mich

20. Falcon, Oxnard. Calif

21. This protocol was carried out following approval by the Human Experimentation Committe of the University of South Florida Medical School, and according to its guidelines.

22. Appreciation is expressed to Mrs. Betty Nager and Mrs. Constance Lang for their excellent technical assistance.

23. Reyuests for reprints should be addressed to: S. H. Pross. Ph. D.. Department of Medical Mierobiology. University of South Florida College of Medicine, Tampa, Fla. 33612 (USA).

24. Reccived for publication May 14, 1976.

25. Accopted for publication August 17, 1976. 